\title{
RETROGRADE SATELLITES IN THE CIRCULAR PLANE RESTRICTED THREE-BODY PROBLEM
}

\author{
D. BENEST
}

Observatoire, Université de Nice, Le Mont-Gros, 06 Nice, France

Characteristics and stability of simple-periodic retrograde satellites of the lighter body are presented for Hill's case and for all values of the mass ratio $m_{2} /\left(m_{1}+m_{2}\right)$ between 0 and 0.5 .

Nonperiodic orbits are presented for some values of the ratio near a critical one, and a new family of double-periodic orbits is found to take an important part in the stability on nonperiodic orbits, so that they counterbalance the instability of simpleperiodic family.

\section{DISCUSSION}

$T$. Inoue: Après avoir calculé beaucoup d'orbites contenant des orbites stables est-ce que vous avez trouvé des conditions analytiques pour que les orbites soient stables?

D. Benest: Je ne l'ai pas encore cherché, mais ce serait certainement très intéressant, si elles existent. 